\title{
Feasibility Study on Provision of Park and Ride Facility at Hebbal Intersection - Bengaluru
}

\author{
Manjunath S Sharanappanavar \\ Professor, KLECET, Chikodi-591201
}

\begin{abstract}
Transportation system management is one of the most important and current need for solving urban travel problems. The possibility of reducing congestion by managing within the existing system is the need of the hour. One of such management technique is the provision of Park and Ride facility. The present study identifies the different Park and Ride facilities implemented around the world in general and looks at provision of Suburban Park and Ride facility in particular. The proposed site is located along the boundary the Bangalore metropolitan area. Traffic surveys were carried out to know about the traffic and travel characteristics. Detailed analysis was carried out to arrive at the possible travel demand and capacity of the Park and Ride facility. Opinion survey was carried out to evaluate the willingness of commuters to use the facility and amount of fare to be collected. The resulting mode shift was estimated. The cost of construction and revenue generated with the facility is also calculated. The results indicate that there will be 19\% reduction in private vehicles travelling to the CBD area from the proposed site. However it is also found that there will be $6.8 \%$ increase in private vehicles travelling from the catchment area to the Park and Ride facility.
\end{abstract}

Keywords: Transportation system management, Park and Ride, Traffic Surveys, Opinion Survey.

\section{Background}

\subsection{Introduction}

Park and Ride lots are parking facilities provided along the perimeter of the CBD area. These act as uncongested collection points receiving automobiles travelling into the CBD area. Such an action reduces the number of automobiles travelling towards congested areas and can be classified as a viable Transportation System Management Action.

\subsection{Classification}

The Park and Ride facility types can be classified based on functional characteristics into six types. These are

1) Informal Park and Ride Lots,

2) Opportunistic or Joint Use Lots,

3) Park and Pool Lots

4) Suburban Park and Ride lots

5) Intermodal Transit Center

6) Satellite Parking Facilities

Based on distance to destination market four classifications can be made as follows

1. Suburban Park and Ride Lots

2. Remote Long-Distance Lots

3. Local Urban Park and Ride Lots

4. Peripheral Park and Ride Lots

\subsection{Selection of Study Area}

According to American Association of State Highway and Transport Officials(AASHTO), suburban park and ride lots are defined as lots that are typically between 6.4 and 48.5 kilometers from the $\mathrm{CBD}$ and that provide an intermodal or change-of-mode service. The requirement is that these should be located along the outer edges of the urban landscape. They should have the potential to collect traffic as close as possible to the origin and act as a transfer cum intermodal change points. The expected modal change is in between private and public transportation. Hence the following guidelines were formulated in the selection of Park and Ride lot.

1) $P+R$ lot should be located at the interface between $C B D$ and suburban areas.

2) It should serve as ideal collection point for suburban catchment area.

3) It should have sufficient space to allow for offsite parking with minimal capital cost.

4) It should be of close proximity to public transportation system.

5) A majority of traffic should pass through the $P+R$ site.

\subsection{Objectives of the Study}

The following are the objectives of the study

1) To evaluate the traffic and travel characteristics of the site

2) To arrive at the possible demand for Park and Ride Lot

3) To design parking spaces.

4) To estimate the feasibility of the Park and Ride lot

\section{Study Area Profile}

The proposed site is located at Hebbal Intersection in Bengaluru as shown in Figure 1. It is located at $11 \mathrm{~km}$ from the city center. It is located along the outer ring road at the intersection of NH-4 and NH-7. A flyover is provided at this junction to separate the traffic coming from the highways. A lake is situated on one side with barren land on the other side. A railway line runs parallel to the road on the remaining side.

The road demarcates the urban and suburban areas in the North of Bengaluru. The suburban travellers coming from the North either pass over the flyover or pass through the intersection. Due to inadequate road network in the suburban area, the dwellers use their private vehicles to travel to their destination in the CBD areas. Hence a Park and Ride facility at this intersection will provide a nearby access for these 


\section{International Journal of Science and Research (IJSR) \\ ISSN (Online): 2319-7064 \\ Index Copernicus Value (2013): 6.14 | Impact Factor (2014): 5.611}

dwellers to park their vehicles at this facility and use the public transport to travel to their destination. Thus it will usage. Based on these characteristics it assumed to be an bring about a modal shift and increase in public transport

ideal location for providing $\mathrm{P}+\mathrm{R}$ facility.

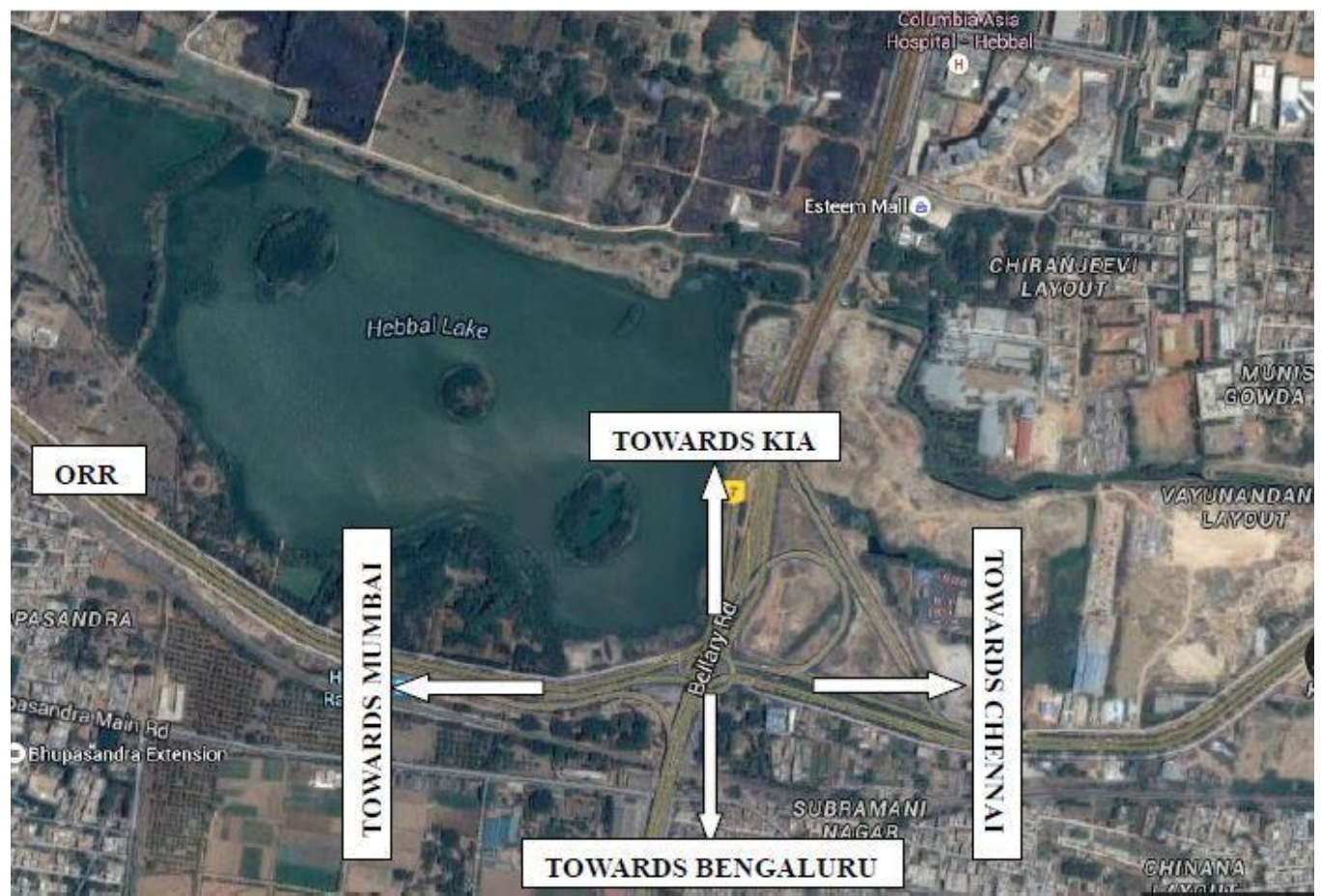

Figure 1: Plan of the Hebbal Intersection

\section{Study Methodology}

In order to examine the feasibility of providing Park and Ride facility an attempt was made to study the characteristics of the site. As this is new system to be implemented in the country, guidelines from research papers and policies developed around the world were used to arrive at a scientific approach to the study. A framework was developed as shown in figure 2 below.

\section{Surveys}

The following traffic surveys were conducted to assess the characteristics of the project site. The surveys were carried out on two weekdays and one weekend. The following traffic surveys were carried out at site -1 . Classified volume count survey, 2. Origin and Destination survey, 3. Opinion survey and 4.Willingness to pay survey. Origin and Destination survey was carried out to assess the catchment area for the park and ride lot and travel distances from the site. Opinion survey and willingness to pay survey was done to estimate the passenger demand of the park and ride lot. The travel routes were named as shown in figure 3 .

\begin{tabular}{|c|c|}
\hline Turning movement survey & $\begin{array}{c}\text { Two weekdays and one weekend - } \\
\text { Morning and evening peak hours }\end{array}$ \\
\hline $\begin{array}{c}\text { Origin and Destination } \\
\text { survey }\end{array}$ & $\begin{array}{c}\text { Two weekdays and one weekend - } \\
10 \% \text { sample size }\end{array}$ \\
\hline
\end{tabular}

\begin{tabular}{|c|c|}
\hline $\begin{array}{c}\text { Opinion and Willingness to } \\
\text { pay survey }\end{array}$ & $\begin{array}{c}\text { Two weekdays and one weekend - } \\
10 \% \text { sample size }\end{array}$ \\
\hline
\end{tabular}

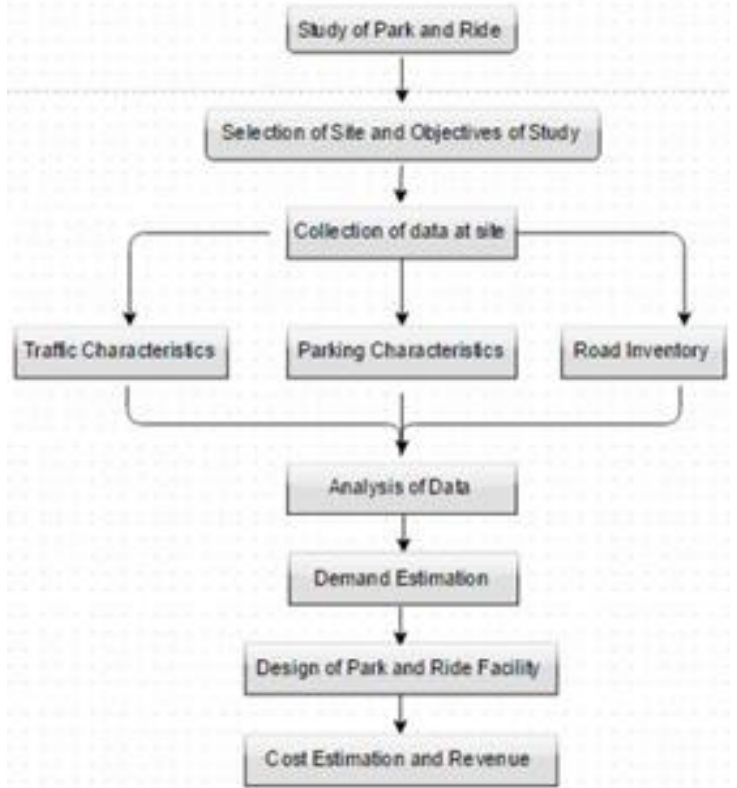

Figure 2: Framework for Study 


\section{International Journal of Science and Research (IJSR) \\ ISSN (Online): 2319-7064}

Index Copernicus Value (2013): 6.14 | Impact Factor (2014): 5.611

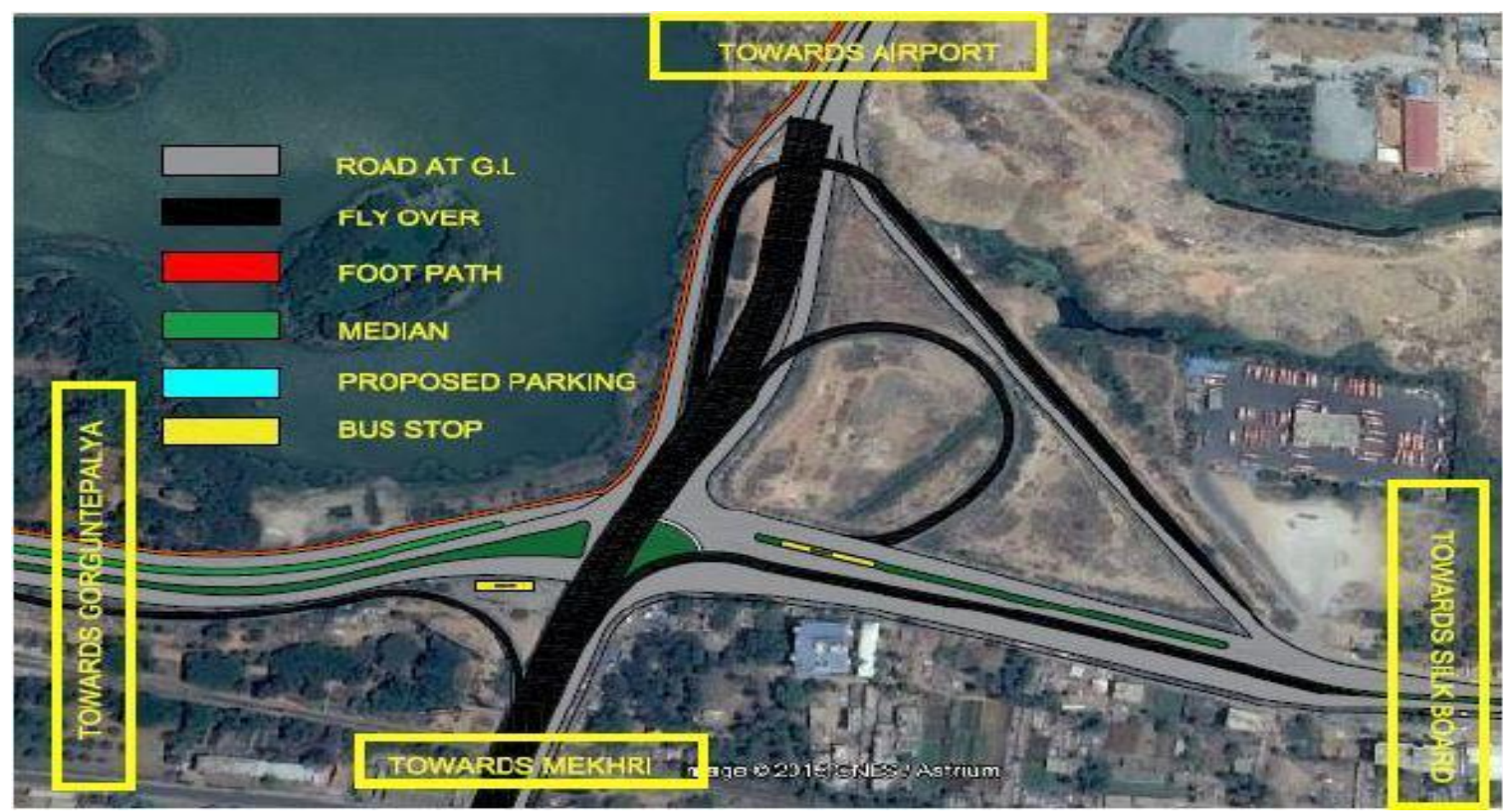

Figure 3: Identified travel destinations from the site

\section{Analysis of Data}

\subsection{Traffic and Travel Characteristics}

Table 1 shows the category of roads and the LOS on them. It is found that all the roads are travelling at LOS E or F.
However due to land restrictions viz., lake on one side, railway track on the other side with temple nearby, it is not possible to go road widening. However a proposal for underpass to separate conflicting traffic is under consideration by authorities.

Table 1: Capacity and LOS of Hebbal Intersection

\begin{tabular}{|c|c|c|c|c|c|c|}
\hline DIRECTION & $\begin{array}{c}\text { No. of } \\
\text { LANE, } \mathrm{m}\end{array}$ & CATEGORY OF ROAD & $\begin{array}{c}\text { PHV } \\
(\mathrm{pcu} / \mathrm{hr})\end{array}$ & $\begin{array}{c}\text { CAPACITY } \\
(\mathrm{pcu} / \mathrm{hr})\end{array}$ & V/C & LOS \\
\hline Silkboard To Gurugunte Palya & 2 & Arterial (2L,D) & 6921 & 6857 & 1.01 & $\mathrm{~F}$ \\
\hline Silkboard To Airport & 2.6 & Sub Arterial (2L,UD,1W) & 4475 & 7057 & 0.63 & $\mathrm{D}$ \\
\hline Silkboard To Mekhri & 1.7 & sub Arterial (2L,UD,1W) & 6310 & 4614 & 1.37 & $\mathrm{~F}$ \\
\hline Gurugunte Palya To Airport & 2.6 & sub Arterial (2L,UD,1W) & 5061 & 7057 & 0.72 & $\mathrm{E}$ \\
\hline Gurugunte Palya To Silkboard & 2.3 & Arterial (2L,D) & 7019 & 6243 & 1.12 & $\mathrm{~F}$ \\
\hline Airport To Silkboard & 2.6 & sub Arterial (2L,UD,1W) & 5680 & 7057 & 0.8 & $\mathrm{E}$ \\
\hline Airport To Mekhri & 2 & Arterial (2L,D) & 7190 & 6857 & 1.05 & $\mathrm{~F}$ \\
\hline Airport To Guruguntepalya & 2 & sub Arterial (2L,UD,1W) & 4535 & 5429 & 0.84 & $\mathrm{E}$ \\
\hline Mekhri To Airport & 2 & Arterial (2L,D) & 6629 & 6857 & 0.97 & $\mathrm{E}$ \\
\hline Mekhri To Gurugunte Palya & 1.6 & sub Arterial (2L,UD,1W) & 4033 & 4343 & 0.93 & $\mathrm{E}$ \\
\hline Mekhri To Silkboard & 2.1 & sub Arterial (2L,UD,1W) & 4724 & 5700 & 0.83 & $\mathrm{E}$ \\
\hline
\end{tabular}

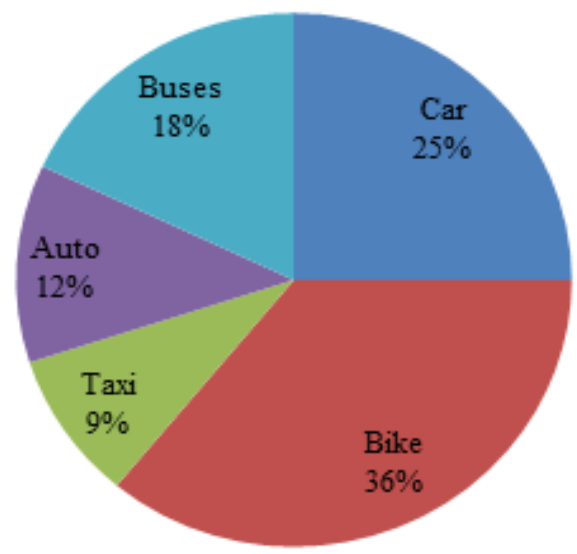

Figure 4: Modal Split

Volume 4 Issue 11, November 2015 www.ijsr.net 


\section{International Journal of Science and Research (IJSR) \\ ISSN (Online): 2319-7064 \\ Index Copernicus Value (2013): 6.14 | Impact Factor (2014): 5.611}

Figure 4 shows the Modal share of the present traffic. It is found that car and bikes own $61 \%$ of the modal share. Also the ratio of public to private transportation is $1: 1.6$

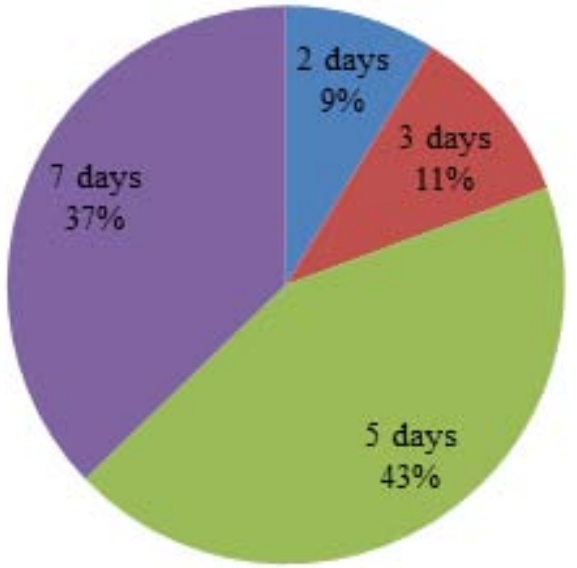

Figure 5: Frequency of Travel

Figure 5 shows the frequency of travel by the commuters. It is found that nearly $80 \%$ of the travellers are regular commuters along the route. Most of the trips made by commuters are business and work trips.

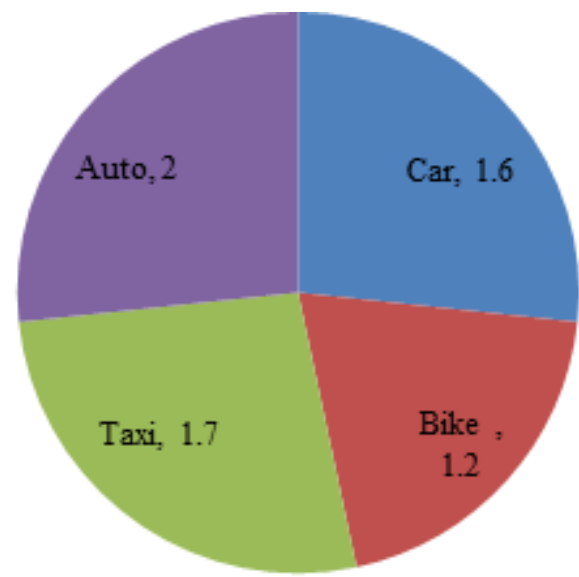

Figure 6: Average Occupancy of Vehicles
Figure 6 shows the frequency of travel by the commuters. It is found that nearly $80 \%$ of the travellers are regular commuters along the route. Most of the trips made by commuters are business and work trips.

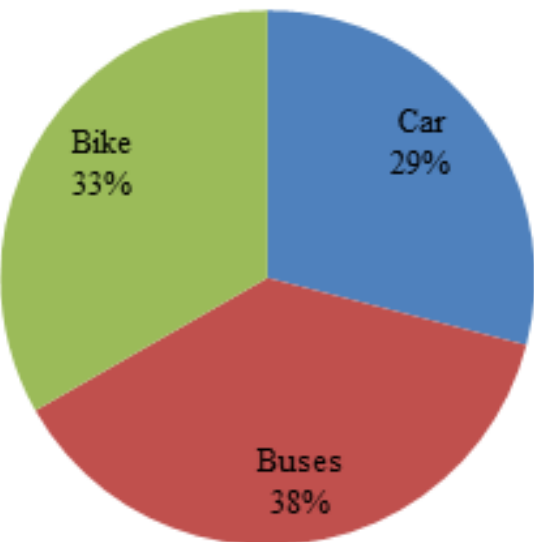

Figure 7: Feel of Journey

Figure 7 shows the average occupancy of the different vehicle. It is found that cars, taxi and two wheelers are carrying passengers less than half of their occupancy level. It is found that the travelers are not willing and/ or interested to go for car sharing or ride sharing programs.

\subsection{Traffic Demand}

Traffic growth rate was estimated using socioeconomic indicators viz., Net State Domestic Product (NSDP), Gross Domestic Product (GDP) and past registration of vehicles in Karnataka. The elasticity values obtained were used to estimate the growth rates. The projected traffic volume is shown in Table 2.

Table 2: Projected traffic volume for year 2030

\begin{tabular}{|c|c|c|c|c|c|c|}
\hline DIRECTION & $\begin{array}{c}\text { No. of Lane, } \\
\mathbf{m}\end{array}$ & $\begin{array}{c}\text { Category of } \\
\text { Road }\end{array}$ & $\begin{array}{c}\text { PHV (pcu/hr) } \\
\text { Present }\end{array}$ & $\begin{array}{c}\text { PHV (pcu/hr). }- \\
\mathbf{2 0 2 0}\end{array}$ & $\begin{array}{c}\text { PHV (pcu/hr). }- \\
\mathbf{2 0 2 5}\end{array}$ & $\begin{array}{c}\text { PHV (pcu/hr). - } \\
\mathbf{2 0 3 0}\end{array}$ \\
\hline MEKHRI TO & 1.6 & $\begin{array}{c}\text { sub Arterial } \\
(2 \mathrm{~L}, \mathrm{UD}, 1 \mathrm{~W})\end{array}$ & 4033 & 6177 & 9461 & 14490 \\
\hline GURUGUNTE PALYA & 2.1 & $\begin{array}{c}\text { sub Arterial } \\
(2 \mathrm{~L}, \mathrm{UD}, 1 \mathrm{~W})\end{array}$ & 4724 & 7235 & 11081 & 16971 \\
\hline $\begin{array}{c}\text { MEKHRI TO } \\
\text { SILKBOARD }\end{array}$ & 2.1 & & & \\
\hline
\end{tabular}

\subsection{Travel Demand}

As the present project is a pilot study, willingness to shift survey was carried out to estimate the demand for the project. The scope for development of utility equations and discrete choice modeling was not possible at this stage.

The Origin-Destination survey was carried out to identify the sub-urban areas which are feeders to the Park and Ride lots.
The results of O-D survey are shown in Table 3. The values shown are inclusive of all types of vehicles. With the results obtained from O-D survey the catchment area was delineated as shown in Figure 9. It was found that the radius of catchment area was having a radius of $5 \mathrm{~km}$. It was found ideal as it will be feasible to provide alternate Park and Ride lots at other locations of the sub-urban areas. 


\section{International Journal of Science and Research (IJSR) \\ ISSN (Online): 2319-7064}

Index Copernicus Value (2013): 6.14 | Impact Factor (2014): 5.611

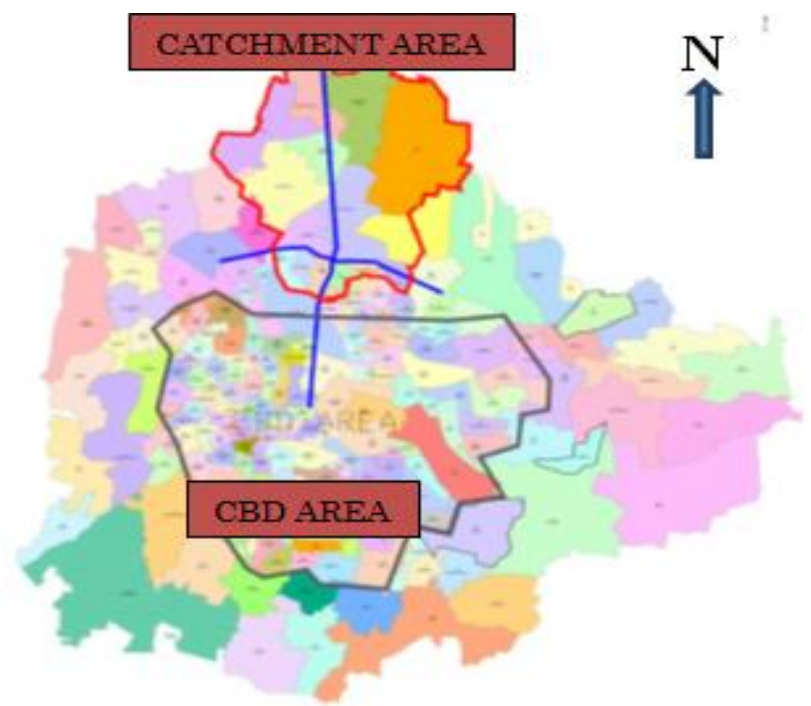

Figure 8: Sub-urban catchment area for the Park and Ride Lot

\begin{tabular}{|c|c|c|c|c|c|c|}
\hline DIRECTION & $\begin{array}{c}\text { No. of Lane, } \\
\text { m }\end{array}$ & $\begin{array}{c}\text { Category of } \\
\text { Road }\end{array}$ & \begin{tabular}{|c|} 
PHV \\
(pcu/hr) Present
\end{tabular} & $\begin{array}{c}\text { PHV } \\
\text { (pcu/hr). -2020 }\end{array}$ & \begin{tabular}{|c|} 
PHV \\
(pcu/hr). -2025
\end{tabular} & $\begin{array}{c}\text { PHV } \\
\text { (pcu/hr). }-2030\end{array}$ \\
\hline $\begin{array}{c}\text { SILKBOARD TO } \\
\text { GURUGUNTE PALYA }\end{array}$ & 2 & $\begin{array}{l}\text { Arterial } \\
(2 \mathrm{~L}, \mathrm{D})\end{array}$ & 6921 & 10600 & 16235 & 24865 \\
\hline $\begin{array}{l}\text { SILKBOARD TO } \\
\text { AIRPORT }\end{array}$ & 2.6 & $\begin{array}{l}\text { Sub Arterial } \\
(2 \mathrm{~L}, \mathrm{UD}, 1 \mathrm{~W})\end{array}$ & 4475 & 6854 & 10497 & 16077 \\
\hline $\begin{array}{l}\text { SILKBOARD TO } \\
\text { MEKHRI }\end{array}$ & 1.7 & $\begin{array}{c}\text { sub Arterial } \\
(2 \mathrm{~L}, \mathrm{UD}, 1 \mathrm{~W})\end{array}$ & 6310 & 9664 & 14801 & 22669 \\
\hline $\begin{array}{c}\text { GURUGUNTE PALYA } \\
\text { TO AIRPORT }\end{array}$ & 2.6 & $\begin{array}{l}\text { sub Arterial } \\
(2 \mathrm{~L}, \mathrm{UD}, 1 \mathrm{~W})\end{array}$ & 5061 & 7751 & 11871 & 18181 \\
\hline $\begin{array}{l}\text { GURUGUNTE PALYA } \\
\text { TO SILKBOARD }\end{array}$ & 2.3 & $\begin{array}{c}\text { Arterial } \\
(2 \mathrm{~L}, \mathrm{D})\end{array}$ & 7019 & 10750 & 16464 & 25216 \\
\hline $\begin{array}{l}\text { AIRPORT TO } \\
\text { SILKBOARD }\end{array}$ & 2.6 & $\begin{array}{l}\text { sub Arterial } \\
(2 \mathrm{~L}, \mathrm{UD}, 1 \mathrm{~W})\end{array}$ & 5680 & 8699 & 13323 & 20405 \\
\hline AIRPORT TO MEKHRI & 2 & $\begin{array}{c}\text { Arterial } \\
(2 \mathrm{~L}, \mathrm{D})\end{array}$ & 7190 & 11012 & 16866 & 25832 \\
\hline $\begin{array}{c}\text { AIRPORT TO } \\
\text { GURUGUNTEPALYA }\end{array}$ & 2 & $\begin{array}{l}\text { sub Arterial } \\
(2 \mathrm{~L}, \mathrm{UD}, 1 \mathrm{~W})\end{array}$ & 4535 & 6946 & 10638 & 16293 \\
\hline MEKHRI TO AIRPORT & 2 & $\begin{array}{l}\text { Arterial } \\
(2 \mathrm{~L}, \mathrm{D})\end{array}$ & 6629 & 10153 & 15550 & 23816 \\
\hline
\end{tabular}

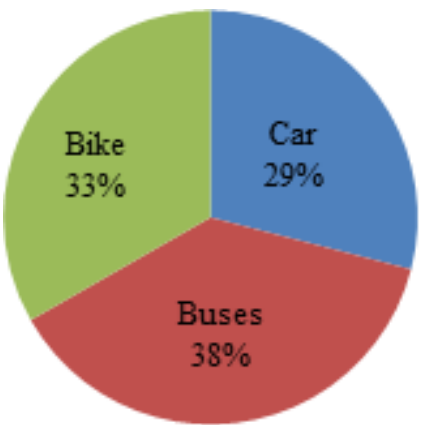

Figure 9 shows the percentage of travellers who are willing to use Park and Ride lot. Based on this data the approximate demand for the Park and Ride lot was estimated as shown in Table 4. Bus-2W indicates the number of bus commuters who will use their private vehicles to travel from their origin to the Park and Ride facility. Later they will use public transportation to reach their destination.

Figure 9: Willingness to use Park and Ride lot 


\section{International Journal of Science and Research (IJSR) \\ ISSN (Online): 2319-7064}

Index Copernicus Value (2013): 6.14 | Impact Factor (2014): 5.611

Table 3: O-D matrix at the Hebbal Intersection

\begin{tabular}{|c|c|c|c|c|c|c|c|c|c|c|c|c|}
\hline O/D & $\begin{array}{c}\text { Bana } \\
\text { Swadi }\end{array}$ & Hennur & $\begin{array}{c}\text { Hsr } \\
\text { Layout }\end{array}$ & $\begin{array}{c}\text { Indira } \\
\text { Nagar }\end{array}$ & $\begin{array}{c}\text { K.R. } \\
\text { Puram }\end{array}$ & $\begin{array}{c}\text { Kalyan } \\
\text { Nagar }\end{array}$ & $\begin{array}{c}\text { Marath } \\
\text { Halli }\end{array}$ & Nagawar & $\begin{array}{c}\text { Silk } \\
\text { Board }\end{array}$ & $\begin{array}{c}\text { Tin } \\
\text { Factory }\end{array}$ & $\begin{array}{c}\text { White } \\
\text { Feild }\end{array}$ & $\begin{array}{c}\text { GRAND } \\
\text { TOTAL }\end{array}$ \\
\hline Amrutha Halli & & & $2.1 \%$ & & $2.5 \%$ & & $1.3 \%$ & & & & & $5.9 \%$ \\
\hline Bhoop Sandhra & & & & & & & $2.1 \%$ & & & $2.1 \%$ & $1.7 \%$ & $5.9 \%$ \\
\hline Byatarayana Pura & & & & & $1.7 \%$ & & & & $1.7 \%$ & & $1.7 \%$ & $5.0 \%$ \\
\hline CBI & - & - & - & - & - & - & $1.7 \%$ & - & - & - & $2.5 \%$ & $4.2 \%$ \\
\hline Dasara Halli & - & - & - & - & - & - & - & - & $2.5 \%$ & - & - & $2.5 \%$ \\
\hline Devi Nagar & - & - & - & - & $4.2 \%$ & - & - & - & - & - & - & $4.2 \%$ \\
\hline Esteem Mall & - & - & - & - & - & - & - & - & $3.8 \%$ & - & $2.1 \%$ & $5.9 \%$ \\
\hline Hebbal & $4.6 \%$ & $1.7 \%$ & $2.5 \%$ & - & $2.5 \%$ & - & - & - & $2.1 \%$ & - & - & $13.4 \%$ \\
\hline Jakkuru & - & - & $2.1 \%$ & - & - & $1.7 \%$ & - & - & - & $2.5 \%$ & - & $6.3 \%$ \\
\hline Kempapur & - & - & - & - & $2.1 \%$ & - & - & - & $2.1 \%$ & $2.1 \%$ & $2.1 \%$ & $8.4 \%$ \\
\hline Kodige Halli & - & - & - & - & - & - & $1.7 \%$ & - & - & $2.1 \%$ & $2.1 \%$ & $5.9 \%$ \\
\hline Nagena Halli & - & - & - & - & - & - & - & $1.7 \%$ & $1.7 \%$ & $2.1 \%$ & - & $5.5 \%$ \\
\hline Sahakar Nagar & - & - & - & - & - & - & $2.1 \%$ & - & - & $4.2 \%$ & $2.5 \%$ & $8.8 \%$ \\
\hline Sanjay Nagar & - & - & - & - & - & - & - & - & $2.5 \%$ & - & - & $2.5 \%$ \\
\hline Sanjeevini Nagar & - & $2.5 \%$ & - & - & - & - & - & $2.5 \%$ & - & $2.1 \%$ & $0.0 \%$ & $7.1 \%$ \\
\hline Yelahanka & - & - & - & $2.1 \%$ & - & - & - & - & - & $2.1 \%$ & $2.1 \%$ & $6.3 \%$ \\
\hline Grand Total & $4.6 \%$ & $4.2 \%$ & $6.7 \%$ & $2.1 \%$ & $13.0 \%$ & $1.7 \%$ & $10.9 \%$ & $4.2 \%$ & $16.4 \%$ & $19.3 \%$ & $16.8 \%$ & $100.0 \%$ \\
\hline
\end{tabular}

In order to estimate the demand for Park and Ride lot the traffic volume on the following road stretches was considered. GURUGUNTE PALYA TO SILKBOARD, AIRPORT TO SILKBOARD,AIRPORT TO GURUGUNTEPALYA. These were selected on the basis that these carry traffic towards the CBD area. The primary goal of $\mathrm{P}+\mathrm{R}$ lot is to reduce the same. The volume of traffic on these road stretches were multiplied with percentages of willingness of commuters to shift to $\mathrm{P}+\mathrm{R}$ mode. The values obtained are shown in Table 4.
Table 4: Estimated demand for the Park and Ride Lot

\begin{tabular}{|c|c|c|c|c|}
\hline Mode/Year & $\begin{array}{c}2015 \\
\text { (veh/day) }\end{array}$ & $\begin{array}{c}2020 \\
\text { (veh/day) }\end{array}$ & $\begin{array}{c}2025 \\
\text { (veh/day) }\end{array}$ & $\begin{array}{c}2030 \\
\text { (veh/day) }\end{array}$ \\
\hline Bus $-2 \mathrm{~W}$ & 1179 & 1692 & 2430 & 3488 \\
\hline Car & 1249 & 1794 & 2575 & 3697 \\
\hline 2W & 2047 & 2939 & 4220 & 6058 \\
\hline Total & 4475 & 6425 & 9225 & 13243 \\
\hline
\end{tabular}

The resulting modal shift was approximately estimated and shown in Table 5.

Table 5: Modal distribution with provision of Park and Ride facility

\begin{tabular}{|c|c|c|c|c|c|c|}
\hline Mode & $\begin{array}{c}\text { Present } \\
\text { Mode Share }\end{array}$ & $\begin{array}{c}\text { Present } \\
\text { Traffic } \\
\text { (PCU/Hr) }\end{array}$ & $\begin{array}{c}\text { Percentage } \\
\text { willing to shift }\end{array}$ & $\begin{array}{c}\text { Estimated } \\
\text { Traffic } \\
\text { (PCU/Hr) }\end{array}$ & $\begin{array}{c}\text { Percentage } \\
\text { change w.r.t Total } \\
\text { Volume (pcu/hr) }\end{array}$ & $\begin{array}{c}\text { Total percentage } \\
\text { reduction in } \\
\text { Private vehicles }\end{array}$ \\
\hline Car & $25 \%$ & 4308 & $29 \%$ & 1250 & 7.25 & \multirow{2}{*}{19.13} \\
\hline $2 \mathrm{~W}$ & $36 \%$ & 6204 & $33 \%$ & 2047 & 11.88 & 13 \\
\hline
\end{tabular}

The available capacity of the site was measured by taking the dimensions of the available area for parking at the site as shown in Figure 10. The parking areas were named A1, A2 and $\mathrm{A} 3$ for convenience. The site are located such that it facilitates the easy parking and travel for each direction under consideration such that they are utilized to the fullest. From the site measurements the area available are shown. The areas designated were proposed to be mixed parking lots for cars and bikes. The adopted standard slot sizes for cars, $2 \mathrm{~W}$ and drive ways are shown in Table 6.
Table 6: Adopted standard size for Park and Ride lot

\begin{tabular}{|c|c|}
\hline Category & Size \\
\hline Car & $2.7 \mathrm{~m} \times 6 \mathrm{~m}$ \\
\hline $2 \mathrm{~W}$ & $0.9 \mathrm{~m} \times 1.8 \mathrm{~m}$ \\
\hline Driveway for Car & $5.5 \mathrm{~m}$ \\
\hline Driveway for $2 \mathrm{~W}$ & $2.5 \mathrm{~m}$ \\
\hline
\end{tabular}

Using the site measurements and adopted standard sizes the capacity of the Park and Ride lots was estimated as shown in Table 7. It is evident that the present on-street parking system will sustain for another 5 years. However by 2020 it is required to upgrade this facility to a multilevel car parking system to cater for the demand.

Table 7: Present capacity v/s Total demand of the Park and Ride lot

\begin{tabular}{|c|c|c|c|c|c|}
\hline $\begin{array}{l}\text { Lot } \\
\text { No. }\end{array}$ & Present Capacity & $\begin{array}{l}\text { Total Demand - } \\
2015\end{array}$ & $\begin{array}{c}\text { Total Demand- } \\
2020\end{array}$ & $\begin{array}{c}\text { Total Demand- } \\
2025 \\
\end{array}$ & $\begin{array}{c}\text { Total Demand - } \\
2030\end{array}$ \\
\hline A1 & $1300-C+1685-2 W$ & \multirow{3}{*}{$\begin{aligned} 1249 & -\mathrm{C}+3226 \\
& -2 \mathrm{~W}\end{aligned}$} & \multirow{3}{*}{$\begin{array}{c}1794-C+4631 \\
-2 W\end{array}$} & \multirow{3}{*}{$\begin{array}{c}2575-C+6650 \\
-2 W\end{array}$} & \multirow{3}{*}{$\begin{array}{c}3697-\mathrm{C}+9546 \\
-2 \mathrm{~W} \\
\end{array}$} \\
\hline $\mathbf{A 2}$ & $969-2 W$ & & & & \\
\hline A3 & $777-2 \mathrm{~W}$ & & & & \\
\hline
\end{tabular}




\section{International Journal of Science and Research (IJSR) \\ ISSN (Online): 2319-7064}

Index Copernicus Value (2013): 6.14 | Impact Factor (2014): 5.611

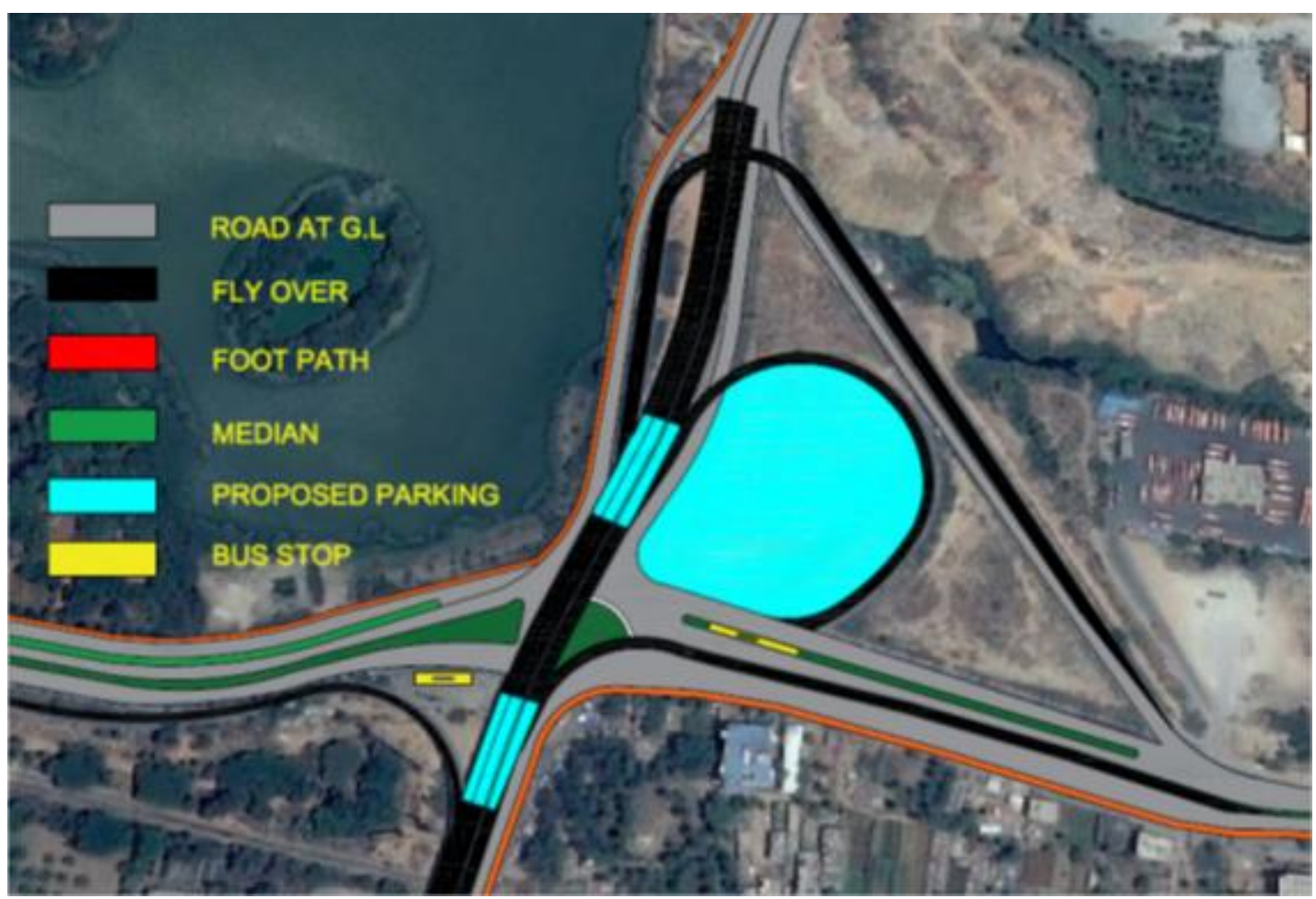

Figure 10: Proposed Park and Ride lot

Figure 11 shows the results of willingness to pay survey. It is found that nearly $43 \%$ of the commuters are willing to pay $10 \mathrm{Rs} /$ day fee for parking their vehicles and around 33\% are willing to pay $20 \mathrm{Rs} /$ day. The possible revenue that could be generated was estimated assuming a charge of $10 /-$ for $2 \mathrm{~W}$ parking and 20/- for Cars. The total revenue generated will be as shown in Table 8.

Table 8: Estimated revenue from Park and Ride lots

\begin{tabular}{|c|c|c|c|c|}
\hline $\begin{array}{c}\text { Mode/ } \\
\text { Year }\end{array}$ & $\mathbf{2 0 1 5}$ & $\mathbf{2 0 2 0}$ & $\mathbf{2 0 2 5}$ & $\mathbf{2 0 3 0}$ \\
\cline { 2 - 5 } & Rs/Annum & Rs/Annum & Rs/Annum & Rs/Annum \\
\hline Bus $-\mathbf{2 W}$ & 1850440.5 & 2655594 & 3813885 & 5474416 \\
\hline Car & 3920611 & 5631366 & 8082925 & 11604883 \\
\hline $\mathbf{2 W}$ & 3212766.5 & 4612760.5 & 6623290 & 9508031 \\
\hline Total & $\mathbf{8 9 , 8 3 , 8 1 8 . 0 0}$ & $\mathbf{1 , 2 8 , 9 9 , 7 2 0 . 5 0}$ & $\mathbf{1 , 8 5 , 2 0 , 1 0 0 . 0 0}$ & $\mathbf{2 , 6 5 , 8 7 , 3 3 0 . 0 0}$ \\
\hline
\end{tabular}

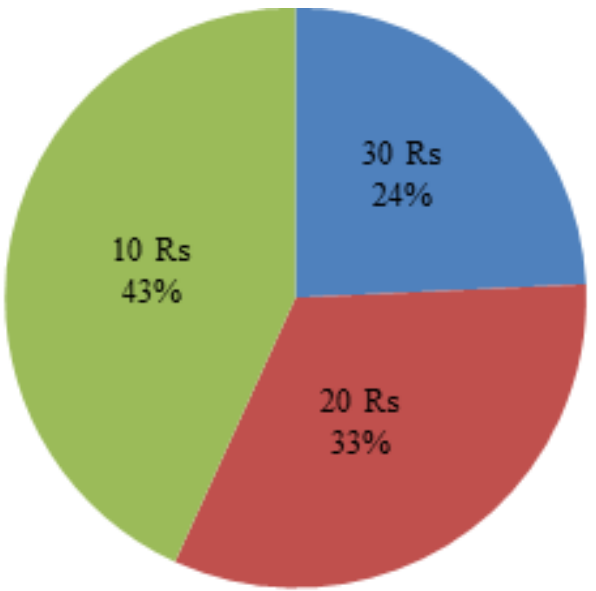

Figure 11: Willingness to Pay

The construction of Park and Ride facility requires civil and electronic works as well as manpower. A detailed estimate was made to arrive at the total cost of construction of the facility. The rates were adopted from current SR of Karnataka state. The detailed estimate is shown in Table 9. The estimate does not include provision of multi-storied parking facility.
Table 9: Detailed estimate for construction of Park and Ride facility

\begin{tabular}{|c|c|c|c|c|c|}
\hline No. & Item & Unit & Quantity & Rate & Amount \\
\hline 1 & Concrete Pavers & Brass & 506 & 4400 per Brass & $22,26,400 /-$ \\
\hline 2 & $\begin{array}{l}\text { Lighting } \\
\text { Assembly }\end{array}$ & No. & 188 & 7000 per no. & $13,16,000 /-$ \\
\hline 3 & Electronic Gates & No. & 11 & 50000 per no. & $5,50,000 /-$ \\
\hline 4 & $\begin{array}{c}\text { Fare collection } \\
\text { machines }\end{array}$ & No. & 11 & 15000 per no. & $1,65,000 /-$ \\
\hline 5 & Computers & No. & 11 & 25000 per no. & $2,75,000 /-$ \\
\hline 6 & $\begin{array}{c}\text { Sign Boards - } \\
\text { MS }\end{array}$ & No. & 11 & 3000 per no. & $33,000 /-$ \\
\hline 7 & $\begin{array}{l}\text { Sign Boards - } \\
\text { Infr. }\end{array}$ & No & 22 & 4145 per no. & $91,190 /-$ \\
\hline 8 & Paint & Sqm & 109.35 & 108 per sqm & $11,801 /-$ \\
\hline 9 & CCTV Camera & No. & 12 & 2000 per no. & $24,000 /-$ \\
\hline 10 & Manpower & No. & 11 & 10000 per no. & $110000 /-$ \\
\hline 11 & Maintenance & $\begin{array}{l}\text { Lump } \\
\text { sum }\end{array}$ & $\begin{array}{c}\text { Per } \\
\text { facility }\end{array}$ & $\begin{array}{c}200000 \text { per } \\
\text { annum }\end{array}$ & $200000 /-$ \\
\hline \multicolumn{5}{|c|}{ Total Cost of Construction } & $50,02,391 /-$ \\
\hline
\end{tabular}




\section{International Journal of Science and Research (IJSR) \\ ISSN (Online): 2319-7064}

Index Copernicus Value (2013): 6.14 | Impact Factor (2014): 5.611

\section{Results \& Conclusions}

The following results and conclusions were arrived at from the study

1) From figure 10 it is found that nearly $33 \%$ of $2 \mathrm{~W}$ users, $29 \%$ of car users and $38 \%$ of bus commuters are willing to shift and use Park and Ride facility.

2) From figure 12 it is found that majority of the commuters are willing to pay a parking fee in the range of Rs $10-20$ per day for using the facility.

3) It is estimated that with the provision of Park and Ride facility nearly $19.13 \%$ of traffic travelling to CBD area will shift to public transport in the current year.

4) It is estimated that with the provision of Park and Ride facility there will be $6.8 \%$

5) increase in private transportation in the catchment area.

6) It is found that there will considerable amount of revenue generated with the provision of Park and Ride facility and will be sufficient for construction and maintenance of the facility.

\section{Scope for Further Study}

1) The study can be extended by conducting SP and RP survey and discrete choice modelling to arrive at travel demand.

2) The cost-benefit analysis of the project can be carried out for various scenarios and alternatives.

3) The possibility of identifying such sites along the boundary of the metropolitan area and proposing Park and Ride facilities can be looked upon.

\section{References}

[1] L. G. Nungesser and N. P. Ledbetter, Federal, "Procedures for Estimating Park-and-Ride Demand in Large Texas Cities" Interim Report, Highway Administration (Texas Transportation Institute Texas A\&M University), College Station, TX, February 1987.

[2] U. R. Abdus-Samad and W.L. Grecco, "Predicting Park 'N Ride Parking Demand, - Purdue University," Joint Highway Research Project Purdue University, West Lafayette, IN, December 1972.

[3] D. Bolger, D. Colquhoun, and J. Morrall, "Planning and Design of Park-and-Ride Facilities for the Calgary Light Rail Transit System," Transportation Research Record No. 1361, Washington, DC, 1992.

[4] Draft Preliminary Report - "Park-n-Ride Evaluation - A Technical Appendix to the RTD Strategic Plan," Regional Transit District, Denver, CO, 1994.

[5] Kathy Kerchowskas and Ashish K., "Park and Ride Planning Manual," Volume III, Sen - University of Illinois at Chicago Circle, U. S.Department of Transportation Research \& Special Programs Administration (DOT-RSPA-DPB-78-11), Springfield, VA, November 1977.

[6] McLean, VA, "Park-and-Ride Facilities - Guidelines for Planning Design and Operation," Daniel Consultants, Inc., Federal Highway Administration, January 1986.

[7] John D.Edwards, Parking, "the Parking Handbook for Small Communities, Institute of Transportation
Engineers and National Trust for Historic Preservation," 1994.

[8] Bus-Based Park \& Ride, "A Good Practice Guide, The English Historic Towns Forum, Huntingdon Centre, The Vineyards," The Paragon, Bath BA1 5NA, England, June 1993.

[9] Park \& Ride Lot Analysis, Houston METRO, October 1989, Metropolitan Transit Authority of Harris County, Texas, Houston,Texas.1

\section{Author Profile}

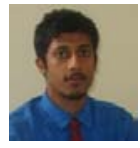

Prof Manjunath S Sharanappanavar received the B.E degree in Civil Engineering from KLE College of Engineering and Technology, Belagavi (VTU University) in 2013 and completed the M.tech degree in Transportation Engineering from REVA Institute of technology and Management, Bengaluru, Karnataka, India (VTU University) in the year 2015. Presently with KLE CET, Chikodi, Karnataka, India as a Assistant Professor. 